\title{
Coronary artery bypass grafting in diabetic patients: Should we still use the saphenous vein graft? A review of literature in the past 15 years
}

\author{
Alberto Molardi ${ }^{1}$, Filippo Benassi ${ }^{1}$, Francesco Nicolini ${ }^{2}$, Francesco Maestri ${ }^{2}$, Tiziano Gherli ${ }^{2}$ \\ ${ }^{1}$ Dipartimento Cardio-Nefro-Polmonare, UO Di Cardiochirurgia, Azienda Ospedaliero-Universitaria di Parma, Parma, Italy \\ ${ }^{2}$ Sezione di Cardiochirurgia, Dipartimento di Medicina Clinica e Sperimentale, Università degli Studi di Parma, Parma, Italy \\ Email: alberto.molardi@gmail.com
}

Received 23 May 2013; revised 23 June 2013; accepted 5 July 2013

Copyright (C 2013 Alberto Molardi et al. This is an open access article distributed under the Creative Commons Attribution License, which permits unrestricted use, distribution, and reproduction in any medium, provided the original work is properly cited.

\begin{abstract}
The burden of diseases associated with diabetes mellitus is dramatic: adults with diabetes mellitus are 2 to 4 times more likely to have cardiovascular diseases than those without it, and at least $65 \%$ will die because of diabetes complications. The revascularization strategy in these types of patients included percutaneous coronary interventions with bare metal stents or medicated stents and surgical coronary artery bypass grafting (CABG), but it is well known that in the diabetic patient with two or more vessel disease, the surgical strategy allows the best mid- and longterm results. Moreover, benefits of CABG surgery are limited by life expectancy of the most common type of graft, the saphenous vein (SV). Nearly 40 years after the introduction of bypass surgery, the rate of vein graft failure remains at high levels. Several arterial conduits had been studied as alternative conduits to SV: the Right Internal Thoracic Artery (RITA), the Radial Artery (RA), the Gastroepiploic Artery (GEA) and the Inferior Epigastric Artery (IEA), 40 years ago. The aim of our article is to review the scientific literature of the past 15 years to answer this question: are we ready to treat the diabetic patient, with a completely arterial revascularization, avoiding the use of the great saphenous vein grafts?
\end{abstract}

Keywords: Total Arterial Revascularization; Coronary Artery Bypass Grafting; Diabetes; Review

\section{INTRODUCTION}

The burden of diseases associated with diabetes mellitus is dramatic: adults with diabetes mellitus are 2 to 4 times more likely to have cardiovascular diseases than those without it, and at least $65 \%$ will die because of diabetes complications [1].

The national burden of cardiovascular diseases caused by diabetes mellitus is increasing, at an unprecedented rate in all western countries [1,2].

Cardiovascular disease in diabetics is clinically challenging because they tend to be extensive with multivessel involvement [3,4].

It is why surgical revascularization has been reported to be well suited for diabetic patients $[5,6]$.

Typically, the elderly are the patients waiting for coronary artery bypass grafting (CABG) surgery with diabetes mellitus. Female gender is increasing in the diabetic population. Diabetic patients often have a history of hypertension and myocardial infarction. Frequently, they have manifestations of congestive heart disease, resulting in NYHA classification III-IV. It has been shown that diabetic patients have a smaller vessel diameter [7], and statistically they have three-vessel disease more frequently and a lower left ventricular ejection fraction [8, 9].

The revascularization strategy in these types of patients included percutaneous coronary interventions with bare metal stents or medicated stents and surgical coronay artery bypass grafting, but it's well known that in the diabetic patient with two or more vessel disease, the surgical strategy allows the best mid- and long-term results [10].

Moreover, the benefits of CABG surgery remain limited by the life expectancy of the most common type of graft, the saphenous vein. Nearly 40 years after the introduction of bypass surgery, the rate of vein graft failure remains at high levels [11].

The introduction of the left internal thoracic artery (LITA) graft radically changed the long term patency 
and survival of patients who underwent CABG [12]. This conduit has shown a remarkable patency rate in several long-term series all around the world. So the introduction of the first arterial conduit has opened to the research of others arterial conduits which could be used with the same results of the LITA.

Several arterial conduits had been studied as alternative ones to saphenous vein (SV): the right internal thoracic artery (RITA), the Radial Artery (RA), the gastroepiploic artery (GEA) and the inferior epigastric artery (IEA) [13].

The aim of our article is to review the scientific literature of the past 15 years to answer to this question: are we ready to treat the diabetic patient with a completely arterial revascularization, avoiding the use of the great saphenous vein grafts?

\section{MATERIALS AND METHODS}

Our search strategy was: Medline 2002 to 2013 using pubmed interface (total arterial) and (CABG) and (diabetes).

More than 35 articles were found; from these 24 articles were identified as providing the best evidence to answer the question (Table 1).

\section{RESULTS}

\subsection{The Bilateral Internal Mammary Artery (BIMA) and the Multiple Internal Mammary Artery (MIMA)}

RITA possesses the same molecular and cellular characteristics that contribute to a unique resistance to atherosclerosis and extremely high long term patency rates as the LITA. The vasoactivity of this arterial conduit has also well characterized: the RITA produces significantly more prostaciclin, a vasodilator and platelet inhibitor, than the saphenous vein and as well as the LITA. The harvest technique is similar to the LITA and it has been proposed as a skeletonized or pedicled graft for the proximal right coronary artery (RCA) or as a skeletonized or pedicled free graft for the branches of the left coronary artery (LCA) as a Y graft anastomosed to the LITA or an another arterial graft as the radial artery (RA) or a venous graft [14].

Both conduits used as a direct graft or a Y graft seem to have a positive effect on the outcome of diabetic patient undergoing CABG procedures.

The practice of using multiple arterial conduits for CABG is supported by reports showing their early operative morbidity and mortality results to be equivalent or better than for CABG with a single arterial graft [15-17].

Formica, et al. and Dorman, et al. founded a 12 to 15 years improvement in the late outcome of patients who underwent CABG with the use of BIMA $[2,18]$.
Apparently, none of the surgical techniques utilized to perform operations demostrated a superiority in terms of graft patency, in-hospital and late mortality and morbidity [2,19-21].

LITA and RITA have been used as peduncolated or skeletonized graft, with direct anastomosis on the target vessels or in composite grafts (Y graft), used to perform the revascularization of a single coronary branch or more coronary branches $[19,21]$ but the type of utilized surgical technique didn't influence the outcomes of the surgical therapy.

Dorman, et al., Rankin, et al., Nasso, et al., Parsa, et al., and Loker, et al. emphasized how the use of a second arterial graft is sufficient to improve the long term quality of life of the patient and their rate of cardiac related mortality and morbidity [2,19-22].

In all these studies, the incidence of surgical wound infections and mediastinitis is comparable to non-diabetic patients.

Only one study has reported data in contrast to those listed above: Saito, et al. [23] compared the use of SIMA versus BIMA in a large sample of 7702 cases with a propensity matched analysis and he found that the use of BIMA did not affect either short-term survival as postoperative mortality was low in both groups or overall morbidity despite higher incidence of deep sternal infection. This study has the limitation of a 30 days post-intervention follow up and the finding of an higher rate of wound infection is not reported in other propensity matched studies [2,22,24,25].

\subsection{The Radial Artery (RA)}

The use of a radial artery as a conduit for coronary artery bypass grafting was first described by Carpentier in 1973 [26]. Early patency rates were poor and the interest in the use of this conduit faded. The radial artery possesses a pronounced medial layer and is highly vasoreactive. Cosmetic concerns have also been cited as a deterrent for radial artery usage.

Surgeons' interest in radial artery as a graft for CABG has a known revival in the last $20-25$ years with the improvements of the harvesting techniques [27] and the identification of the pharmacological agents to prevent the graft spasm $[13,28]$.

The long-term outcome after CABG depends on graft patency. Previous angiographic observational studies have shown that the RA achieved excellent short- (96\% $100 \%)$, mid- (94\% - 97\%), and long-term graft patency (84\% - 96\%) when used as either an aortocoronary bypass or a composite graft [13,29-31].

Patency rates of the RA have exceeded those of SV grafts at all time points and are comparable to other arterial grafts. Many reports have shown better outcomes of the RA compared with the SV [30,32-43], though some 
Table 1. List of the selected articles reviewed in our work.

\begin{tabular}{|c|c|c|c|c|c|c|}
\hline $\begin{array}{c}\text { Author and } \\
\text { Periodical }\end{array}$ & Goal & $\begin{array}{c}\text { Design: Number of } \\
\text { patients Type of study } \\
\text { Mono-Multicenter } \\
\text { Randomized Follow-up }\end{array}$ & $\begin{array}{l}\text { Type of } \\
\text { Conduits }\end{array}$ & $\begin{array}{l}\text { Angiogram } \\
\text { Follow } \\
\text { up/Patency Rate }\end{array}$ & $\begin{array}{l}\text { Primary } \\
\text { Endpoint }\end{array}$ & Conclusion \\
\hline
\end{tabular}

\begin{tabular}{cc}
\hline Locker, & $\begin{array}{c}\text { Comparate Multiarterial } \\
\text { et al. } 2012 \\
\text { CABG group to LITA + SV } \\
\text { group outcomes }\end{array}$ \\
& $\begin{array}{c}\text { To determine the factors } \\
\text { that contribute to } \\
\text { in-hospital mortality } \\
\text { and long-term survival } \\
\text { et al. } 2013 \\
\text { in young patients (aged } \\
\text { less than 65) undergoing } \\
\text { CABG }\end{array}$
\end{tabular}

To assess 20-year clinical benefits of MIMA

Rankin, grafting and to evaluate the et al. $2007 \quad$ possible effects of two different MIMA configurations outcomes of bilateral internal mammary artery 2013 single IMA (SIMA)
in patients who
underwent isolated
coronary artery bypass
grafting (CABG)

initial report of the early and late outcomes of

Schwann, et al. 2009 sequential RA grafts in a large contemporary CABG series
To evaluate early Saito, et al. (BIMA) compared with

No. Pts: 8622

Diabetic/Non Diabetic Type of study: retrospective analysis Centers Involved: one center

Randomization: None

Follow up: 15 years

No. Pts: 5967

Diabetic/Non Diabetic under 65 years Type of study:

retrospective analysis of a perspective database Centers Involved: one center

Randomization: None

Follow up: 7.9 years

No. Pts: 867

Diabetic/Non Diabetic Type of study: retrospective analysis Centers Involved: 2 Centers

Randomization: None

Follow up: 20 years

No. Pts: 12229

Diabetic/Non Diabetic Type of study: retrospective analysis of a perspective database Centers Involved: 210 centers

Randomization: None Follow up: perioperative (max 30 days after CABG)

No. Pts: 4663

Diabetic/Non Diabetic Type of study: retrospective analysis Centers Involved: 2 centers

Randomization: None

Follow up: 5.3 years

To determine whether the use of the radial artery (RA) vs the saphenous vein (SV)

Schwann, as the second grafting et al. 2013 conduit with the internal thoracic artery (ITA) confers a late-survival advantage in diabetes mellitus (DM)
No. Pts: 2281 Diabetic Type of study: retrospective analysis Centers Involved: one center

Randomization: None

Follow up: 16 years

$\begin{array}{lll}\text { LITA-RITA- } & \text { None } & \text { Perioperative } \\ \text { RA-SV } & & \text { Mortality } \\ & & \bullet\end{array}$

LITA-RASV

None

- Perioperative Mortality

- Late mortality

LITA-

RITA-

MIMA

None

- all-cause death

- subsequent PCI

- $\mathrm{MI}$

- ReDo CABG

LITA-

BIMA-SV

None

- Perioperative Mortality

- Perioperative Morbidity

LITA-

Yes (symptoms • Late Survival driven)

Patency rate:

- Patency rate of

RA-SV

$71 \%$ for RA

by Angiography
In patients undergoing isolated coronary artery bypass graft surgery with LITA to left anterior descending artery, arterial grafting of the non-left anterior descending vessels conferred a survival advantage at 15 years compared with SV grafting.

Significant factors determining long-term survival in the under-65-year group include: age, atrial fibrillation, diabetes (diet and insulin controlled), LV function, cerebrovascular disease, dialysis, LITA usage, "urgent” operation status, CKMB and peripheral vascular disease.

Data confirm clinical benefits of MIMA grafting in multivessel coronary disease to 20 years of follow-up.

BIMA did not affect either short-term survival, or overall morbidity despite higher incidence of deep sternal infection Note: BIMA (Bilateral Internal Mammary Artery).

Sequential RA grafting is a safe method for maximizing arterial revascularization and is associated with excellent 10-year survival that seems to be superior to conventional or ITA/SV

CABG results.

RA grafting confers a significant late-survival advantage and, thus, supports its liberal use in DM patients undergoing multivessel CABG. 


\section{Continued}

\begin{tabular}{|c|c|c|c|c|c|c|}
\hline $\begin{array}{l}\text { Hwang, } \\
\text { et al. } 2010\end{array}$ & $\begin{array}{l}\text { To evaluate the } \\
\text { influence of diabetes } \\
\text { mellitus (DM) on 5-year } \\
\text { angiographic results and } \\
\text { long-term clinical } \\
\text { outcomes in patients who } \\
\text { underwent total arterial } \\
\text { off-pump coronary } \\
\text { revascularization for } \\
\text { mul-tivessel coronary } \\
\text { disease }\end{array}$ & $\begin{array}{l}\text { No. Pts: } 558 \\
\text { Diabetic/Non Diabetic } \\
\text { Type of study: } \\
\text { retrospective analysis } \\
\text { Centers Involved: } \\
\text { one center } \\
\text { Randomization: None } \\
\text { Follow up: } 5 \text { years }\end{array}$ & $\begin{array}{l}\text { LITA- } \\
\text { RITA-RA- } \\
\text { rGEA Only } \\
\text { OPCABG }\end{array}$ & $\begin{array}{l}\text { Yes Patency rate } \\
\text { (in DM group): } \\
\text { Early: } 98.2 \% \\
\text { 1-Year: } 95.3 \% \\
\text { 5-Year: } 94.6 \%\end{array}$ & $\begin{array}{l}\text { - Long-term } \\
\text { survival } \\
\text { - } \text { cardiac deaths } \\
\text { - major advanced } \\
\text { cardiovascular or } \\
\text { cerebral events }\end{array}$ & $\begin{array}{l}\text { Diabetes mellitus did not } \\
\text { affect 5-year angiographic } \\
\text { results, long-term survival, } \\
\text { and clinical events in } \\
\text { patients with multivessel } \\
\text { coronary disease who } \\
\text { underwent total } \\
\text { arterial off-pump } \\
\text { revascularization. }\end{array}$ \\
\hline $\begin{array}{l}\text { Hoffman, } \\
\text { et al. } 2013\end{array}$ & $\begin{array}{l}\text { using radial artery (RA) } \\
\text { conduit(s) would improve } \\
\text { outcomes and long term } \\
\text { survival for diabetic } \\
\text { patients undergoing CABG } \\
\text { with Left Internal Thoracic } \\
\text { Artery (LITA) and RA } \\
\text { grafts, with or without } \\
\text { additional saphenous vein } \\
\text { (SV) when compared with } \\
\text { outcomes for patients } \\
\text { bypassed with LITA and } \\
\text { SV but no RA }\end{array}$ & $\begin{array}{c}\text { No. Pts: } 1843 \\
\text { Diabetic/Non Diabetic } \\
\text { Type of study: } \\
\text { retrospective analysis } \\
\text { Centers Involved: } \\
\text { one center } \\
\text { Randomization: None } \\
\text { Follow up: } 15 \text { years } \\
\text { Propensity matched } \\
\text { study }\end{array}$ & $\begin{array}{l}\text { LITA- } \\
\text { RA-SV }\end{array}$ & None & $\begin{array}{l}\text { - all cause } \\
\text { mortality } \\
\text { determined from } \\
\text { the Social } \\
\text { Security Death } \\
\text { Index }\end{array}$ & $\begin{array}{c}\text { For diabetic patients having } \\
\text { CABG with LITA, use of } \\
\text { radial artery conduit adds } \\
\text { a substantial and sustained } \\
\text { survival advantage } \\
\text { compared to LITA and vein. } \\
\text { Optimal revascularization } \\
\text { for diabetics with multi } \\
\text { vessel disease is redefined. }\end{array}$ \\
\hline $\begin{array}{l}\text { Dorman, } \\
\text { et al. } 2012\end{array}$ & $\begin{array}{l}\text { we studied the long-term } \\
\text { results of BIMA versus } \\
\text { SIMA grafting in a large } \\
\text { population of diabetic } \\
\text { patients in whom BIMA } \\
\text { grafting was broadly } \\
\text { applied }\end{array}$ & $\begin{array}{l}\text { No. Pts: } 828 \text { Diabetic } \\
\text { Type of study: } \\
\text { retrospective analysis } \\
\text { Centers Involved: } \\
\text { one center } \\
\text { Randomization: None } \\
\text { Follow up: } 30 \text { years } \\
\text { Propensity matched study }\end{array}$ & $\begin{array}{l}\text { LITA-RITA } \\
\text { SIMA } \\
\text { versus } \\
\text { BIMA }\end{array}$ & None & $\begin{array}{ll}\text { - } & \text { Long-term } \\
\text { survival } \\
\text { - } \\
\text { - } \text { cardiac deaths } \\
\text { cardior advanced } \\
\text { cerebral events }\end{array}$ & $\begin{array}{l}\text { Compared with SIMA } \\
\text { grafting, BIMA grafting in } \\
\text { propensity score-matched } \\
\text { patients provides diabetics } \\
\text { with enhanced survival } \\
\text { without any increase in } \\
\text { perioperative morbidity or } \\
\text { mortality Note: SIMA: } \\
\text { Single Internal Mammary } \\
\text { artery-BIMA: Bilateral } \\
\text { Internal Mammary Artery. }\end{array}$ \\
\hline $\begin{array}{l}\text { Zacharias, } \\
\text { et al. } 2009\end{array}$ & $\begin{array}{l}\text { Compared with SIMA } \\
\text { grafting, BIMA grafting in } \\
\text { propensity score-matched } \\
\text { patients provides diabetics } \\
\text { with enhanced survival } \\
\text { without any increase in } \\
\text { perioperative morbidity } \\
\text { or mortality }\end{array}$ & $\begin{array}{c}\text { No. Pts: } 4743 \\
\text { Diabetic/Non Diabetic } \\
\text { Type of study: } \\
\text { retrospective analysis } \\
\text { Centers Involved: } \\
\text { one center } \\
\text { Randomization: None } \\
\text { Follow up: } 12 \text { years } \\
\text { Propensity matched study }\end{array}$ & $\begin{array}{l}\text { LITA-RITA- } \\
\text { RA-SV }\end{array}$ & None & $\begin{array}{l}\text { - Long-term } \\
\text { survival } \\
\text { - cardiac deaths } \\
\text { - major advanced } \\
\text { cardiovascular or } \\
\text { cerebral events } \\
\end{array}$ & $\begin{array}{c}\text { All-arterial } \\
\text { revascularization is } \\
\text { associated with significantly } \\
\text { better 12-year survival } \\
\text { compared with the standard } \\
\text { single ITA with saphenous } \\
\text { vein CABG operation, in } \\
\text { particular for triple-vessel } \\
\text { disease patients. The } \\
\text { completeness of } \\
\text { revascularization of the } \\
\text { underlying coronary disease } \\
\text { is critical for maximizing } \\
\text { the long-term benefits of } \\
\text { arterial-only grafting. }\end{array}$ \\
\hline $\begin{array}{l}\text { Singh, } \\
\text { et al. } 2008\end{array}$ & $\begin{array}{l}\text { This study examines the } \\
\text { impact of diabetes on } \\
\text { graft patency, 1-year } \\
\text { postcoronary artery } \\
\text { bypass grafting, using } \\
\text { data from a multicenter } \\
\text { randomized trial }\end{array}$ & $\begin{array}{c}\text { No. Pts: } 561 \\
\text { Diabetic/Non Diabetic } \\
\text { Type of study: } \\
\text { retrospective analysis on } \\
\text { a multi-center } \\
\text { randomized trial } \\
\text { Centers Involved: } \\
\text { a multi-center } \\
\text { randomized trial } \\
\text { Randomization: Yes } \\
\text { Follow up: } 12 \text { years }\end{array}$ & $\begin{array}{l}\text { LITA- } \\
\text { RA-SV }\end{array}$ & $\begin{array}{c}\text { Yes; } 1 \text { year } \\
\text { angiographic } \\
\text { follow up of } \\
\text { RA grafts } \\
\text { Diabetic: } 85.6 \% \\
\text { Non Diabetic: } \\
\text { 90.3\% }\end{array}$ & $\begin{array}{l}\text { - } 1 \text { year mortality } \\
\text { - } \text { Redo for } \\
\text { revascularization } \\
\text { - Myocardial } \\
\text { infarction } \\
\text { - } 1 \text { year rate of } \\
\text { angiographic } \\
\text { occlusion in RA } \\
\text { vs SV }\end{array}$ & $\begin{array}{l}\text { Coronary artery bypass } \\
\text { grafting occlusions were } \\
\text { more common among } \\
\text { diabetics versus } \\
\text { nondiabetics at 1-year } \\
\text { angiography, mainly } \\
\text { because of more frequent } \\
\text { SV graft failure in diabetics. } \\
\text { Radial artery, compared } \\
\text { with SV grafting, is } \\
\text { protective in both diabetic } \\
\text { and nondiabetic patients. }\end{array}$ \\
\hline
\end{tabular}




\author{
We present our \\ experience with total \\ arterial myocardial \\ Formica, revascularization with \\ et al. 2004 bilateral internal thoracic \\ artery (BITA) and right \\ gastroepiploic artery \\ (rGEA)
}

No. Pts: 174

Diabetic/Non Diabetic Type of study: retrospective analysis Centers Involved: one center

Randomization: None Follow up: 9 years
Suma, Assesting the use of et al. 2007 rGEA for CABG
Parsa et al. 2013
To assess single institutional outcomes with multiple internal thoracic artery grafting for guidance with future clinical decisions

To evaluate early and 1-year results of arterial Cho, et al. Y composite grafts 2010 situ left internal thoracic artery were studied. Off-pump CABG only

To evaluate the effect of a double arterial graft on the outcome of CABG

Nasso, et al. 2009 operations and investigate which second choice arterial conduit its better for improving outcomes

To evaluate the use of RA Schwann, as second choice conduit et al. 2008 in revascularization of diabetics patients
No. Pts: 626

Diabetic/Non Diabetic Type of study: retrospective analysis Centers Involved: two centers

Randomization: Yes Follow up: 2 year

No. Pts: 1516 Diabetic Type of study: retrospective analysis Centers Involved: one center

Randomization: None Follow up: 2 year
This study indicates that the myocardial revascularization in young patients with three-vessel disease using exclusively pedicle BITA and rGEA provides excellent 9-year patient survival and improvement in terms of freedom from return of angina pectoris and freedom from any cardiac-related event. These results encourage the more extensive use of BITA and rGEA in selected patients with three-vessel coronary disease.

\author{
LITA-RITA \\ MIMA \\ versus SIMA \\ None \\ or MI \\ - Postoperative PCI \\ - ReDo CABG \\ - All causes death
}

- Subsequent AMI
This study confirms improved patient's outcomes with multiple internal thoracic artery grafting.

\begin{tabular}{|c|c|c|}
\hline $\begin{array}{l}\text { LITA- } \\
\text { RITA-rGEA } \\
\text { rGEA-LITA } \\
\text { (Y graft) } \\
\text { versus } \\
\text { RITA-LITA } \\
\text { (Y graft) }\end{array}$ & $\begin{array}{l}\text { Yes } 1 \text { year } \\
\text { follow up } \\
\text { rGEA patency } \\
\text { rate: } 97 \% \\
\text { RITA patency } \\
\text { rate: } 95 \%\end{array}$ & $\begin{array}{l}\text { - Perioperative } \\
\text { Mortality and } \\
\text { morbidity } \\
\text { - Patency rate at } \\
1 \text { year with } \\
\text { angiographic } \\
\text { follow up }\end{array}$ \\
\hline
\end{tabular}

LITA-RITANone RA-SV

- In Hospital outcome

- 2 years freedom from all cause death and acdverse cardiac event free survival grafts using the RITA or RGEA showed comparable results including patency postoperatively.

Revascularization with 2 arterial conduits offers better midterm event-free survival than a single arterial graft, irrespective of which second-choice arterial conduit is used (radial artery or right thoracic artery), the simultaneous use of saphenous vein grafts, and the patient's age.

Using radial as a second arterial conduit as opposed to vein grafting did not confer a survival benefit in diabetics.
Construction of Y composite rates early and 1 year
- Early, mid term survival of diabetic patients after CABG
ITA-RA-

None
GEA graft is a suitable conduit with acceptably good patency rate to the distal right or circumflex coronary artery.
- Perioperative morbidity
Early, midterm,

.




\section{Continued}

\author{
To compare the results \\ of composite Y-grafts of \\ the radial artery (RA) and \\ the right gastroepiploic \\ artery (RGEA) proximally \\ Santos, \\ anastomosed to the left \\ et al. 2002 \\ internal thoracic artery \\ (LITA) for CABG \\ evaluated through \\ angiography, in a \\ prospective \\ randomized study
}

The objective of this study is to demonstrate the safety Hassanein, and potential advantages et al. 2010 of bilateral mammary coronary revascularization in patients older than 65 years

16-year experience in 1851 consecutive patients undergoing isolated CABG, using the RA after Tranbaugh, the LITA to LAD graft to et al. 2012 better define the outcomes, long-term survival, patency, and need for rein-tervention after RA grafting

To determine the relative patency rate

Desai, of radial-artery and et al. 2004 saphenous-vein grafts in a randomized trial with a 1-year follow-up

Possati, To asses the long term et al. 2003 patency rate of RA graft
No. Pts: 60 Diabetic Type of study: prospective

randomized study

Centers Involved: one center

Randomization: Yes

Follow up: perioperative

Diabetic/Non Diabetic Type of study:

propensity score analysis

Centers Involved: one center

Randomization: Yes

Follow up: perioperative

No. Pts: 1851

Diabetic/Non Diabetic

Type of study:

retrospective study

Centers Involved:

one center

Randomization: None

Follow up: 15 years
- Early complications after CABG (perioperative AMI, cardiac death, infection)

- Early graft patency
Radial artery had better early results than right gastroepiploic artery. Use of the LITA as inflow graft seems not to affect its good patency. Use of the RGEA as composite graft should not be encouraged.
BIMA-SV None
- Early complications after CABG (perioperative AMI, cardiac death, infection, neurological complications)

- Early graft patency

- Early complications after CABG (perioperative AMI, cardiac death, infection, neurological complications)

LITA-RITA- Patency rate: RA-SV

LITA: $85 \%$ RITA: $80 \%$ RA: $82 \%$

- Long term outcomes

- Early-mid-long term patency rates

No. Pts: 561

Diabetic/Non Diabetic Type of study: randomized

Randomization: None
Yes 1 year after trial study (RAPS) Centers Involved: 13 centers Follow up: 1 year

$\begin{array}{ccc} & \text { Yes 1 year after } & \\ \text { LITA-RA- } & \text { the operation } & \text { - Early patency } \\ \text { SV } & \text { Patency rate } & \text { rate of RA } \\ & \text { RA 91.8\% } & \text { versus SV } \\ & \text { SV } 86.4 \% & \end{array}$

No. Pts: 90 Diabetic/Non Diabetic Type of study: perspective study Centers Involved: one center

Randomization: None Follow up: 10 years
Bilateral internal mammary artery revascularization can be safely performed in patients older than 65 years. T-graft configuration without aortic anastomosis is particularly beneficial in this age group since it avoids aortic manipulation, which is an important risk factor for postoperative stroke.

RA grafting is a highly effective revascularization strategy providing excellent short and long-term outcomes with very low rates of reintervention. RA patency is similar to LITA patency and is much better than SV patency. RA grafting should be more widely utilized in patients undergoing $\mathrm{CABG}$.

Radial-artery grafts are associated with a lower rate of graft occlusion at one year compare with the saphenous-vein grafts. Because the patency of radial-artery grafts depends on the severity of native-vessel stenosis, such grafts should preferentially be used for target vessels with high-grade lesions.

Ten years after surgery, RA grafts have excellent patency and perfect patency rates. Appropriate surgical technique and correct indication are the key factors for long-term RA patency. 


$\begin{array}{cc} & \text { We performed a } \\ & \text { single-center prospective } \\ \text { randomized trial comparing } \\ \text { the angiographic patency } \\ \text { Collins, } \\ \text { et al. 2008 } & \text { of radial artery and } \\ & \text { saphenous vein } \\ \text { aortocoronary bypass } \\ \text { grafts at } 5 \text { years } \\ \text { after surgery }\end{array}$

The second best conduit for coronary artery bypass graft surgery is unclear. We sought to determine if the

Tranbaugh, use of a second arterial

et al. 2010 conduit, the radial artery, would improve long-term survival after CABG using the left internal thoracic artery and saphenous vein

$$
\text { No. Pts: } 90
$$

Diabetic/Non Diabetic Type of study: perspective study Centers Involved: one center

Randomization: None

Follow up: 10 years

$\begin{array}{cc} & \begin{array}{c}\text { Yes } 5 \text { years after } \\ \text { the operation }\end{array} \\ \text { LITA-RA- } & \text { Patency rate: } \\ \text { SV } & \text { RA 98,3\% } \\ & \text { SV 86,4\% }\end{array}$

-

- Midterm patency rate of RA graft versus SV graft versus SV graft

Radial artery aortocoronary bypass grafts to a stenosed branch of the circumflex coronary artery have an excellent patency rate at 5 years. This was significantly better than the patency rate for saphenous vein grafts and comparable to reported patency rates for internal thoracic artery grafts.

Using the LITA, SV, and a RA conduit for CABG results in significantly improved long-term survival compared with using the LITA and SV. The use of two arterial conduits offers a clear and lasting survival advantage, likely due to the improved patency of RA grafts. We conclude that RA conduits should be more widely utilized during CABG.

reported similar long-term graft patency [44-47].

Only the Cleveland Clinic reported worse graft patency of the RA than the SV [48].

Possati, et al. reported the long-term (105 \pm 9 months) graft patency of RA grafts in a series of 90 consecutive CABG patients [36].

The RA graft patency was $88 \%$, which was less than that of the LITA (96\%), but better than that of the SV (53\%). Although these results are encouraging the use of the RA as a complementary arterial conduit with the LITA, there are only a few long-term studies assessing RA graft patency in the setting of a randomized controlled trial.

The Radial Artery Patency Study (RAPS) investigators enrolled 561 patients in 13 centers [49]. In this trial, the RA graft was randomly assigned to bypass in either the right coronary territory or the circumflex coronary territory, with the SV graft used for the opposing territory, which had proximal lesions at least $70 \%$ of occlusion diameter narrowing. Angiography for 440 RA grafts and $440 \mathrm{SV}$ grafts was performed in 440 patients in 1 year. They reported that $8.2 \%$ of RA grafts and $13.6 \%$ of SV grafts were completely occluded ( $\mathrm{P}=0.009$ ). Diffuse narrowing of the graft (string sign) was present in $7.0 \%$ of the RA grafts and only $0.9 \%$ of SV grafts $(P=0.001)$. The absence of severe native vessel stenosis was a risk of graft occlusion and diffuse narrowing of the RA conduit (70\% - 89\% proximal stenosis: $81.7 \%$; $>90 \%$ proximal stenosis: $91.5 \%)$. Patency of the RA grafts was similar in the right coronary and circumflex arteries. These is com- patible with previous reports suggesting that the RA should be limited to grafting to native coronary vessels with a high degree of stenosis ( $>70 \%$ ) because of graft sensitivity to competitive flow and diffuse narrowing [50,51].

Diffuse narrowing of the RA graft is thought to be of little or no clinical consequence because the narrowed graft may improve or work well late in the follow-up. However, cardiologists consider the string sign of the RA graft as a failure. As the string sign at 1 year is unfavorable toward a functioning RA or SV graft, $15.2 \%$ of RA grafts and $14.5 \%$ of SV grafts are occluded or functioning poorly. RA grafting should not be considered in the setting of $<75 \%$ proximal coronary obstruction, especially in the right coronary branches [52].

The RAPS Investigators also reported that diabetes (RR: 1.45, $\mathrm{P}=0.03)$, female gender ( $R R: 1.78, \mathrm{P}=0.02)$, and small target vessel diameter (RR: 2.28, $\mathrm{P}<0.01$ ) are multivariate predictors of graft failure [53,54].

Graft occlusion was more common among diabetic patients (14\% vs 10\%) because of more frequent SV occlusion (19\%) than RA occlusion (10\%). The RA is protective in the small-sized coronary arteries with diffuse diabetic disease. As regards the gender, RA graft occlusion rate at 1 year was similar in men $(8.6 \%)$ and women (5.3\%) $(\mathrm{P}=0.6)$, whereas SV graft occlusion rates were lower in men (12.0\%) than in women (23.3\%). A history of peripheral vascular disease was associated with an elevated risk of RA occlusion, but not with SV occlusion. On the contrary, angiographic studies of patients at the 
Cleveland Clinic found poor graft patency in the RA (51\%) compared with the SV (64\%). As concerns sex, women had significantly worse RA graft patency (39\%) than men (56\%) [30].

The Radial Artery Patency and Clinical Outcome (RAPCO) study, was undertaken to compare angiographic patency and cardiac-event-free survival of the RA graft with that of the free RITA and SV during a 10-year period after CABG [55].

The RA was compared with the free RITA in patients $<70$ years of age and with the SV in patients aged $>75$ years. The 5-year interim results of this single center trial conducted by Buxton, et al. in Australia reported that there were no differences in angiographic graft failure and cardiac events of the patients with the RA compared with the RITA or SV. The 5-year patency rates between the RA and RITA were $95 \%$ vs $100 \%$, respectively, and those between the RA and SV were $87 \%$ vs $94 \%$. However, these results were based on a small number of angiographic studies, and SV graft patency was very much better than in previous reports. The final results up to 10 years should clarify the long-term RA graft patency.

The Radial Artery Versus Saphenous Vein Graft Patency (RSVP) trial was a single-center, prospective, randomized clinical trial designed to compare 5-year patency rates of RA and SV aortocoronary grafts to the circumflex coronary artery [56].

At 5 years, 103 patients among 142 enrolled patients underwent angiography. The graft patency of the RA (98.3\%) was significantly $(\mathrm{P}=0.04)$ better than that of the SV (86.4\%). Graft narrowing occurred in $10 \%$ of patent RA grafts and $23 \%$ of SV grafts $(\mathrm{P}=0.01)$.

In conclusion, despite the poor first outcomes of the RA graft, the progress of harvesting techniques and pharmacological therapy to prevent the radial spasm had lead to re-discover a useful arterial conduit with wide application opportunities expecially on the left coronary branches with patency rates comparable to the RITA's ones and superior to those of the SV graft.

\subsection{The Right Gastroepiploic Artery (rGEA)}

The right GEA represents another interesting option as a conduit for CABG. Several studies demonstrated similarities of this conduit with the internal thoracic artery. Of the other possible arterial conduits, the right gastroepiploic artery (r-GEA) has several advantages, such as providing a comparably sized artery-to-artery anastomosis, necessitating no additional incision in the leg or forearm, and histologic similarity to the ITA, which would suggest long-term patency $[57,58]$.

In 1987, Pym and others authors [59], have independently reported their successful clinical application of the GEA graft for CABG, and now over the last 2 dec- ades, basic research and the clinical application of GEA has widely been undertaken. The GEA graft has a high clinical availability for CABG [60], low incidence of arteriosclerosis [61], and sufficient flow capacity [62].

Its biological and physiological activity have been studied extensively [63,64].

Several investigators have shown that GEA can be used without increased morbidity, particularly in abdominal complications $[65,66]$, and the late survival rate has been excellent in CABG with GEA plus internal thoracic artery grafts $[18,56,67,68]$.

High tendencies to develop vasospasm and competitive flow in moderately stenotic coronary lesions, however, have been indicated as limitations of the in situ RGEA graft, but this tendence to develop spasm seems to be due to the use of pedicled r-GEA, while skeletonized r-GEA appears to have a significantly low rate of spasm [69-72].

Moreover, the lenght of this vessel, if it is used as a composite graft, allows to reach both coronary systems and to achieve a complete arterial revascularization [69].

Suma, et al., in a study published on Circuation [57], a large series of patients who recived a r-GEA graft, demonstrating that r-GEA has a patency rate superior to the SV one.

\subsection{The Inferior Epigastric Artery (IEA)}

The Inferior Epigastric Artery represents an infrequent arterial conduit used as a free graft for CABG. In our research in PubMed we did not find recent articles or trials about the use of this conduit in CABG so this section of our review is to complete the view of arterial conduits which are used or proposed for total arterial grafting.

For some authors, the artery exhibits favorable physiological vasoreactivity characteristics and its lenght, diameter and location are rather variable. After it has been harvested, it is treated like a radial artery in terms of preparation. It is used to create composite Y graft usually with an anastomosis with the LITA, RITA or SV [73].

Some authors reported good patency rate in early postoperative follow up, even with angiography [74], but the patients' series and the lack of mid- and long term follow up can't encourage a wide use of this conduit and it absolutely requires others clinical investigations on larger series of patients.

\section{CONCLUSIONS}

In a review of the literature of the last 15 years, it has been reported the superiority of total arterial coronary grafting in CABG, even in the long term follow-up.

The harvesting of this "addictional" conduit expands 
the operating time, but it has been shown that each of them improve the outcome of the coronaric patients undergoing $\mathrm{CABG}$.

Although diabetes is an independent risk factor for coronary artery disease and graft restenosis, the outcome of the diabetic patient is significantly improved by the use of total arterial grafting.

It is also clear that each arterial vessel we described, especially the radial artery, seems to have particular indications and a preferential anastomosis territory. The wide application and the utilization of these vessels need to be proved by multicenter randomized studies in the future.

Our opinion is that the use of total arterial myocardial revascularization should be encouraged, and cardiac surgery is near to avoid the use of saphenos vein graft in the scheduled coronary patient.

\section{REFERENCES}

[1] Fox, C.S., Coady, S., Sorlie, P.D., D’Agostino, R.B., Pencina, M.J., Vasan, R.S., Meigs, J.B., Levy, D. and Savage, P.J. (2007) Increasing cardiovascular disease burden due to diabetes mellitus: The framingham heart study. Circulation, 115, 1544-1550. doi:10.1161/CIRCULATIONAHA.106.658948

[2] Dorman, M.J., Kurlansky, P.A., Traad, E.A., Galbut, D.L., Zucker, M. and Ebra, G. (2012) Bilateral internal mammary artery grafting enhances survival in diabetic patients: A 30-year follow-up of propensity score-matched cohorts. Circulation, 126, 2935-2942. doi:10.1161/CIRCULATIONAHA.112.117606

[3] Norhammar, A., Malmberg, K., Diderholm, E., Lagerqvist, B., Lindahl, B., Rydén, L. and Wallentin, L. (2004) Diabetes mellitus: The major risk factor in unstable coronary artery disease even after consideration of the extent of coronary artery disease and benefits of revascularization. Journal of the American College of Cardiology, 43, 585-591. doi:10.1016/j.jacc.2003.08.050

[4] Goraya, T.Y., Leibson, C.L., Palumbo, P.J., Weston, S.A., Killian, J.M., Pfeifer, E.A., Jacobsen, S.J., Frye, R.L. and Roger, V.L. (2002) Coronary atherosclerosis in diabetes mellitus: A population-based autopsy study. Journal of the American College of Cardiology, 40, 946-953. doi:10.1016/S0735-1097(02)02065-X

[5] Flaherty, J.D. and Davidson, C.J. (2005) Diabetes and Coronary Revascularization. Journal of the American Medical Association, 293, 1501-1508. doi:10.1001/jama.293.12.1501

[6] Hlatky, M.A., Boothroyd, D.B., Bravata, D.M., Boersma, E., Booth, J., Brooks, M.M., Carrié, D., et al. (2009) Coronary artery bypass surgery compared with percutaneous coronary interventions for multivessel disease: A collaborative analysis of individual patient data from ten randomised trials. Lancet, 373, 1190-1197. doi:10.1016/S0140-6736(09)60552-3

[7] Cariou, B., Bonnevie, L., Mayaudon, H., Dupuy, O., Cec- caldi, B. and Bauduceau, B. (2000) Angiographic characteristics of coronary artery disease in diabetic patients compared with matched non-diabetic subjects. Diabetes, Nutrition \& Metabolism, 13, 134-141.

[8] Jones, R.H., Hannan, E.L., Hammermeister, K.E., Delong, E.R., O’Connor, G.T., Luepker, R.V., Parsonnet, V. and Pryor, D.B. (1996) Identification of preoperative variables needed for risk adjustment of short-term mortality after coronary artery bypass graft surgery. The Working Group Panel on the Cooperative CABG Database Project, 28, 1478-1487.

[9] Birnbaum, D.E. and Lehle, K. (2006) CPB in high-risk groups: CPB in diabetics. Perfusion, 21, 235-238. doi:10.1191/0267659106pf874oa

[10] Patel, M.R., Dehmer, G.J., Hirshfeld, J.W., Smith, P.K. and Spertus, J.A. (2009) ACCF/SCAI/STS/AATS/AHA/ ASNC 2009 appropriateness criteria for coronary revascularization: A report of the American college of cardiology foundation appropriateness criteria task force, society for cardiovascular angiography and interventions, society of thoracic surgeons, American Association for Thoracic Surgery, American Heart Association, and the American Society of Nuclear Cardiology: Endorsed by the American Society of Echocardiography, the Heart Failure Society of America, and the Society of Cardiovascular Computed Tomography. Circulation, 119, 13301352. doi:10.1161/CIRCULATIONAHA.108.191768

[11] Parang, P. and Arora, R. (2009) Coronary vein graft disease: Pathogenesis and prevention. Canadian Journal of Cardiology, 25, e57-e62. doi:10.1016/S0828-282X(09)70486-6

[12] Loop, F.D., Cosgrove, D.M., Lytle, B.W., Thurer, R.L., Simpfendorfer, C., Taylor, P.C. and Proudfit, W.L. (1979) An 11-year evolution of coronary arterial surgery (19681978). Annals of Surgery, 190, 444-455. doi:10.1097/00000658-197910000-00004

[13] Kobayashi, J. (2009) Radial artery as a graft for coronary artery bypass grafting. Circulation Journal, 73, 11781183. doi:10.1253/circj.CJ-09-0322

[14] Cohn, L.H. (2011) Cardiac Surgery in the Adult. McGraw Medical, New York.

[15] Pick, A.W., Orszulak, T.A., Anderson, B.J. and Schaff, H.V. (1997) Single versus bilateral internal mammary artery grafts: 10-year outcome analysis. The Annals of Thoracic Surgery, 64, 599-605. doi:10.1016/S0003-4975(97)00620-6

[16] Zacharias, A., Schwann, T.A., Riordan, C.J., Durham, S.J., Shah, A.S. and Habib, R.H. (2009) Late results of conventional versus all-arterial revascularization based on internal thoracic and radial artery grafting. The Annals Thoracic Surgery, 87, 19-26. doi:10.1016/j.athoracsur.2008.09.050

[17] Hassanein, W., Hegazy, Y.Y., Albert, A., Ennker, I.C., Rosendahl, U., Bauer, S. and Ennker, J. (2010) Short term outcomes of total arterial coronary revascularization in patients above 65 years: A propensity score analysis. Journal of Cardiothoracic Surgery, 5, 25. doi:10.1186/1749-8090-5-25

[18] Formica, F., Ferro, O., Greco, P., Martino A, Gastaldi D, 
and Paolini G. (2004) Long-term follow-up of total arterial myocardial revascularization using exclusively pedicle bilateral internal thoracic artery and right gastroepiploic artery. European Journal Cardio-Thoracic Surgery, 26, 1141-1148. doi:10.1016/j.ejcts.2004.08.027

[19] Rankin, J.S., Tuttle, R.H., Wechsler, A.S., Teichmann, T.L., Glower, D.D. and Califf, R.M. (2007) Techniques and benefits of multiple internal mammary artery bypass at 20 years of follow-up. The Annals of Thoracic Surgery, 83, 1008-1014.

[20] Nasso, G., Coppola, R., Bonifazi, R., Picone, F., Bozzetti, G. and Speziale, G. (2009) Arterial revascularization in primary coronary artery bypass grafting: Direct comparison of 4 strategies-results of the stand-in-Y mammary study. The Journal of Thoracic and Cardiovascular Surgery, 137, 1093-1100. doi:10.1016/j.jtcvs.2008.10.029

[21] Parsa, C.J., Shaw, L.K., Rankin, J.S., Daneshmand, M.A., Gaca, J.G., Milano, C.A., Glower, D.D. and Smith, P.K. (2013) Twenty-five-year outcomes after multiple internal thoracic artery bypass. The Journal of Thoracic and Cardiovascular Surgery, 145, 970-975. doi:10.1016/j.jtcvs.2012.11.093

[22] Locker, C., Shaff, H.V., Dearani, J.A., Joyce, L.D., Park, S.J., Burkhart, H.M., Suri, R.M., et al. (2012) Multiple arterial grafts improve late survival of patients undergoing coronary artery bypass graft surgery. Circulation, 126, 1023-1030. doi:10.1161/CIRCULATIONAHA.111.084624

[23] Saito, A., Miyata, H., Motomura, N., Ono, M., Takamoto, S. and Japan Cardiovascular Surgery Database Organization. (2013) Propensity-matched analysis of bilateral internal mammary artery vs single internal mammary artery in 7702 cases of isolated coronary artery bypass grafting. European Journal Cardio-Thoracic Surgery, in print. doi:10.1093/ejcts/ezt157

[24] Grau, J.B., Ferrari, G., Mak, A.W.C., Shaw, R.E., Brizzio, M.E., Mindich, B.P., Strobeck, J. and Zapolanski, A. (2012) Propensity matched analysis of bilateral internal mammary artery versus single left internal mammary artery grafting at 17-year follow-up: Validation of a contemporary surgical experience. European Journal Cardio-Thoracic Surgery, 41, 770-775.

[25] Kinoshita, T., Asai, T., Suzuki, T., Kambara, A. and Matsubayashi, K. (2011) Off-pump bilateral versus single skeletonized internal thoracic artery grafting in high-risk patients. Circulation, 124, S130-S134. doi:10.1161/CIRCULATIONAHA.110.010892

[26] Carpentier, A.F., Guermonprez, J.L., Deloche, A., Frechette, C. and DuBost, C. (1973) The aorta-to-coronary radial artery bypass graft: A technique avoiding pathological changes in grafts. The Annals of Thoracic Surgery, 16, 111. doi:10.1016/S0003-4975(10)65825-0

[27] Newman, R.V. and Lammle, W.G. (2003) Radial artery harvest using endoscopic techniques. Heart Surgery Forum, 6, E194-E195.

[28] Schwann, T.A., Zacharias, A., Riordan, C.J., Durham, S.J., Shah, A.S. and Habib, R.H. (2008) Does radial use as a second arterial conduit for coronary artery bypass grafting improve long-term outcomes in diabetics? European Journal Cardio-Thoracic Surgery, 33, 914-923. doi:10.1016/j.ejcts.2008.01.062

[29] Calafiore, A.M., Di Giammarco, G., Teodori, G., D’Annunzio, E., Vitolla, G., Fino, C. and Maddestram N. (1995) Radial artery and inferior epigastric artery in composite grafts: Improved midterm angiographic results. The Annals of Thoracic Surgery, 60, 517-523.

[30] Zacharias, A., Habib, R.H., Schwann, T.A., Riordan, C.J., Durham, S.J. and Shah, A. (2004) Improved survival with radial artery versus vein conduits in coronary bypass surgery with left internal thoracic artery to left anterior descending artery grafting. Circulation, 109, 1489-1496. doi:10.1161/01.CIR.0000121743.10146.78

[31] Schwann, T.A., Zacharias, A., Riordan, C.J., Durham, S.J., Shah, A.S. and Habib, R.H. (2009) Sequential radial artery grafts for multivessel coronary artery bypass graft surgery: 10-Year Survival and Angiography Results. The Annals of Thoracic Surgery, 88, 31-39. doi:10.1016/j.athoracsur.2009.03.081

[32] Mediratta, N., Chalmers, J., Pullan, M., McShane, J., Shaw, M. and Poullis, M. (2013) In-hospital mortality and long-term survival after coronary artery bypass surgery in young patients. European Journal Cardio-Thoracic Surgery, 43, 1014-1021. doi:10.1093/ejcts/ezs459

[33] Schwann, T.A., Al-Shaar, L., Engoren, M. and Habib, R.H. (2013) Late effects of radial artery vs saphenous vein grafting for multivessel coronary bypass surgery in diabetics: A propensity-matched analysis. European Journal Cardio-Thoracic Surgery, 1-10. doi:10.1093/ejcts/ezt061

[34] Acar, C., Jebara, V.A., Portoghese, M., Beyssen, B., Pagny, J.Y., Grare, P., Chachques, J.C., Fabiani, J.-N.N., Deloche, A. and Guermonprez, J.L. (1992) Revival of the radial artery for coronary artery bypass grafting. The Annals of Thoracic Surgery, 54, 652-659.

[35] Amano, A., Hirose, H., Takahashi, A. and Nagano, N. (2001) Coronary artery bypass grafting using the radial artery: Midterm results in a Japanese institute. The Annals of Thoracic Surgery, 72, 120-125. doi:10.1016/S0003-4975(01)02706-0

[36] Possati, G., Gaudino, M., Prati, F., Alessandrini, F., Trani, C., Glieca, F., Mazzari, M.A., Luciani, N. and Schiavoni, G. (2003) Long-term results of the radial artery used for myocardial revascularization. Circulation, 108, 13501354. doi:10.1161/01.CIR.0000087402.13786.D0

[37] Da Costa, F.D., Da Costa, I.A., Poffo, R., Abuchaim, D., Gaspar, R., Garcia, L. and Faraco, D.L. (1996) Myocardial revascularization with theradial artery: A clinical and angiographic study. The Annals of Thoracic Surgery, 62, 475-479. doi:10.1016/0003-4975(96)00311-6

[38] Chen, A.H., Nakao, T., Brodman, R.F., Greenberg, M., Charney, R., Menegus, M., Johnson, M., et al. (1996) Early postoperative angiographicassessment of radial grafts used forcoronary artery bypass grafting. The Journal of Thoracic and Cardiovascular Surgery, 111, 1208-1212. doi:10.1016/S0022-5223(96)70223-4

[39] Possati, G., Gaudino, M., Alessandrini, F., Luciani, N., 
Glieca, F., Trani, C., Cellini, C., Canosa, C. and Di Sciascio, G. (2013) Midterm clinical and angiographic results of radial artery grafts used for myocardial revascularization. The Journal of Thoracic and Cardiovascular Surgery, 116, 1015-1021. doi:10.1016/S0022-5223(98)70054-6

[40] Tranbaugh, R.F., Dimitrova, K.R., Friedmann, P., Geller, C.M., Harris, L.J., Stelzer, P., Cohen, B.M., et al. (2012) Coronary artery bypass grafting using the radial artery: Clinical outcomes, patency, and need for reintervention. Circulation, 126, S170-S175. doi:10.1161/CIRCULATIONAHA.111.083048

[41] Tranbaugh, R.F., Dimitrova, K.R., Friedmann, P., Geller, C.M., Harris, L.J., Stelzer, P., Cohen, B. and Hoffman, D.M. (2010) Radial artery conduits improve long-term survival after coronary artery bypass grafting. The Annals of Thoracic Surgery, 90, 1165-1172. doi:10.1016/j.athoracsur.2010.05.038

[42] Hwang, H.Y., Choi, J.S. and Kim, K.B. (2010) Diabetes does not affect long-term results after total arterial offpump coronary revascularization. The Annals of Thoracic Surgery, 90, 1180-1186. doi:10.1016/j.athoracsur.2010.05.021

[43] Hoffman, D.M., Dimitrova, K.R., DeCastro, H., Friedmann, P., Geller, C.M., Ko, W. and Tranbaugh, R.F. (2013) Improving long term outcome for diabetic patients undergoing surgical revascularization by use of the radial artery conduit: A propensity matched study. Journal of Cardiothoracic Surgery, 8, 27. doi:10.1186/1749-8090-8-27

[44] Boylan, M.J., Lytle, B.W., Loop, F.D., Taylor, P.C., Borsh, J.A., Goormastic, M. and Cosgrove, D.M. (1994) Surgical treatment of isolated left anterior descending coronary stenosis. Comparison of left internal mammary artery and venous autograft at 18 to 20 years of follow-up. The Journal of Thoracic and Cardiovascular Surgery, 107, 657-662.

[45] Lemma, M., Mangini, A., Gelpi, G., Innorta, A., Spina, A. and Antona, C. (2004) Is it better to use the radial artery as a composite graft? Clinical and angiographic results of aorto-coronary versus Y-graft. European Journal CardioThoracic Surgery, 26, 110-117. doi:10.1016/j.ejcts.2004.03.020

[46] Gaudino, M., Alessandrini, F., Pragliola, C., Cellini, C., Glieca, F., Luciani, N., Girola, F. and Possati, G. (2004) Effect of target artery location and severity of stenosis on mid-term patency of aorta-anastomosed vs. internal thoracic artery-anastomosed radial artery grafts. European Journal Cardio-Thoracic Surgery, 25, 424-428. doi:10.1016/j.ejcts.2003.11.027

[47] Cameron, J., Trivedi, S., Stafford, G. and Bett, J.H.N. (2004) Five-year angiographic patency of radial artery bypass grafts. Circulation, 110, II23- II26.

[48] Khot, U.N., Friedman, D.T., Pettersson, G.B., Smedira, N.G., Li, J. and Ellis, S.G. (2004) Radial artery bypass grafts have an increased occurrence of angiographically severe stenosis and occlusion compared with left internal mammary arteries and saphenous vein grafts. Circulation, 109, 2086-2091.

\section{doi:10.1161/01.CIR.0000127570.20508.5C}

[49] Desai, N.D., Cohen, E.A., Naylor, C.D., Fremes, S.E. (2004) A randomized comparison of radial-artery and saphenous-vein coronary bypass grafts. The New England Journal of Medicine, 351, 2302-2309. doi:10.1056/NEJMoa040982

[50] Royse, A.G., Royse, C.F., Tatoulis, J., Grigg, L.E., Shah, P., Hunt, D., Better, N. and Marasco, S.F. (2000) Postoperative radial artery angiography for coronary artery bypass surgery. European Journal Cardio-Thoracic Surgery, 17, 294-304. doi:10.1016/S1010-7940(99)00364-4

[51] Maniar, H.S., Sundt, T.M., Barner, H.B., Prasad, S.M., Peterson, L., Absi, T. and Moustakidis, P. (2002) Effect of target stenosis and location on radial artery graft patency. The Journal of Thoracic and Cardiovascular Surgery, 123, 45-52. doi:10.1067/mtc.2002.118686

[52] Nakajimaa, H., Kobayashi, J., Funatsu, T., Shimahara, Y., Kawamura, M., Kawamura, A., Yagihara, T. and Kitamura, S. (2007) Predictive factors for the intermediateterm patency of arterial grafts in aorta no-touch off-pump coronary revascularization. European Journal CardioThoracic Surgery, 32, 711-717. doi:10.1016/j.ejcts.2007.07.025

[53] Singh, S.K., Desai, N.D., Petroff, S.D., Deb, S., Cohen, E.A., Radhakrishnan, S., Schwartz, L., Dubbin, J., Fremes, S.E. (2008) The impact of diabetic status on coronary artery bypass graft patency: Insights from the radial artery patency study. Circulation, 118, S222- S225. doi:10.1161/CIRCULATIONAHA.107.757161

[54] Desai, N.D., Naylor, C.D., Kiss, A., Cohen, E.A., FederElituv, R., Miwa, S., Radhakrishnan, S., Dubbin, J., Schwartz, L. and Fremes, S.E. (2007) Impact of patient and target-vessel characteristics on arterial and venous bypass graft patency: Insight from a randomized trial. Circulation, 115, 684-691. doi:10.1161/CIRCULATIONAHA.105.567495

[55] Buxton, B.F., Raman, J.S., Ruengsakulrach, P., Gordon, I., Rosalion, A., Bellomo, R., Horrigan, M. and Hare, D.L. (2003) Radial artery patency and clinical outcomes: Fiveyear interim results of a randomized trial. The Journal of Thoracic and Cardiovascular Surgery, 125, 1363- 1371. doi:10.1016/S0022-5223(02)73241-8

[56] Collins, P., Webb, C.M., Chong, C.F. and Moat, N.E. (2008) Radial artery versus saphenous vein patency randomized trial: Five-year angiographic follow-up. Circulation, 117, 2859-2864. doi:10.1161/CIRCULATIONAHA.107.736215

[57] Suma, H., Tanabe, H., Takahashi, A., Horii, T., Isomura, T., Hirose, H. and Amano, A. (2007) Twenty years experience with the gastroepiploic artery graft for CABG. Circulation, 116, I188-I191. doi:10.1161/CIRCULATIONAHA.106.678813

[58] Mills, N.L. and Everson, C.T. (1989) Right gastroepiploic artery: A third arterial conduit for coronary artery bypass. The Annals of Thoracic Surgery, 47, 706-711. doi:10.1016/0003-4975(89)90122-7

[59] Suma, H., Fukumoto, H. and Takeuchi, A. (1987) Coronary artery bypass grafting by utilizing in situ right gastroepiploic artery: Basic study and clinical application. 
The Annals of Thoracic Surgery, 44, 394-397. doi:10.1016/S0003-4975(10)63799-X

[60] Saito, T., Suma, H., Terada, Y., Wanibuchi, Y., Fukuda, S. and Furuta, S. (1992) Availability of the in situ right gastroepiploic artery for coronary artery bypass. The Annals of Thoracic Surgery, 53, 266-268. doi:10.1016/0003-4975(92)91330-C

[61] Suma, H., Wanibuchi, Y., Furuta, S., Isshiki, T., Yamaguchi, T. and Takanashi, R. (1991) Comparative study between the gastroepiploic and the internal thoracic artery as a coronary bypass graft. size, flow, patency, histology. European Journal Cardio-Thoracic Surgery, 5, 244-247. doi:10.1016/1010-7940(91)90171-F

[62] Kusukawa, J., Hirota, Y., Kawamura, K., Suma, H., Takeuchi, A., Adachi, I. and Akagi, H. (1989) Efficacy of coronary artery bypass surgery with gastroepiploic artery. Assessment with thallium 201 myocardial scintigraphy. Circulation, 80, I135- I140.

[63] Ochiai, M., Ohno, M., Taguchi, J., Hara, K., Suma, H., Is-shiki, T., Yamaguchi, T. and Kurokawa, K. (1992) Responses of human gastroepiploic arteries to vasoactive substances: Comparison with responses of internal mammary arteries and saphenous veins. The Journal of Thoracic and Cardiovascular Surgery, 104, 453-458.

[64] Takayama, T., Suma, H., Wanibuchi, Y., Tohda, E., Matsunaka, T. and Yamashita, S. (1992) Physiological and pharmacological responses of arterial graft flow after coronary artery bypass grafting measured with an implantable ultrasonic Doppler miniprobe. Circulation, 86, II217-II223.

[65] Suma, H., Wanibuchi, Y., Furuta, S. and Takeuchi, A. (1991) Does use of gastroepiploic artery graft increase surgical risk? The Journal of Thoracic and Cardiovascular Surgery,101, 121-125.

[66] Hirose, H., Amano, A., Takanashi, S. and Takahashi, A. (2002) Coronary artery bypass grafting using the gastroepiploic artery in 1,000 patients. The Annals of Thoracic Surgery, 73, 1371-1379. doi:10.1016/S0003-4975(02)03416-1

[67] Nishida, H., Tomizawa, Y., Endo, M., Koyanagi, H. and Kasanuki, H. (2001) Coronary artery bypass with only in situ bilateral internal thoracic arteries and right gastro- epiploic artery. Circulation, 104, I76-I80. doi:10.1161/hc37t1.094812

[68] Tavilla, G., Kappetein, A.P., Braun, J., Gopie, J., Tjien, A.T.J. and Dion, R.A.E. (2004) Long-term follow-up of coronary artery bypass grafting in three-vessel disease using exclusively pedicled bilateral internal thoracic and right gastroepiploic arteries. The Annals of Thoracic Surgery, 77, 794-799.

[69] Cho, K.R., Hwang, H.Y., Kim, J.-S., Jeong, D.S. and Kim, K.-B. (2010) Comparison of right internal thoracic artery and right gastroepiploic artery $\mathrm{Y}$ grafts anastomosed to the left internal thoracic artery. The Annals of Thoracic Surgery, 90, 744-750.

[70] He, G.-W. (1999) Arterial grafts for coronary artery bypass grafting: Biological characteristics, functional classification, and clinical choice. The Annals of Thoracic Surgery, 67, 277-284. doi:10.1016/S0003-4975(98)01207-7

[71] Glineur, D., D’hoore, W., Khoury, E.l.G., Sondji, S., Kalscheuer, G., Funken, J.-C., Rubay, J., et al. (2008) Angiographic predictors of 6-month patency of bypass grafts implanted to the right coronary artery : A prospective randomized comparison of gastroepiploic artery and saphenous vein grafts. Journal of the American College of Cardiology, 51, 120-125. doi:10.1016/j.jacc.2007.09.030

[72] Santos, G.G., Stolf, N.A.G., Moreira, L.F.P., Haddad, V.L.S., Simões, R.M.C., Carvalho, S.R.V., Salgado, A.A. and Avelar, S.F. (2002) Randomized comparative study of radial artery and right gastroepiploic artery in composite arterial graft for CABG. European Journal CardioThoracic Surgery, 21, 1009-1014. doi:10.1016/S1010-7940(02)00180-X

[73] Ayabe, T., Fukushima, Y., Yoshioka, M. and Onizuka, T. (2003) Clinical outcome of the coronary arterial bypass graft with inferior epigastric artery as a composite graft. Kyobu Geka, 56, 731-737.

[74] Kamata, S., Kasegawa, H., Shimokawa, T., Kasahara, K., Matsushita, Y., Abe, Y., Kitanaka, Y., et al. (1998) Coronary artery bypass grafting with arterial graft alone: Radial artery and inferior epigastric artery used in combination. Kyobu Geka, 51, 393-397. 